\section{Women accept polar challenge}

\section{Munich}

IGNORING; the example set by the US Antarctic research station and others, West Germany has always refused to send women to spend the winter at its own Antarctic station. Nine all-male teams in a row have overwintered at the station.

This autumn, that will change, when nine women will make the long trip from Bremerhaven to the Georg-vonNeumayer-Station on the Ekström shelf ice. The women, trained in survival skills, have important scientific tasks to perform during their 320-day period of isolation from February to December 1990.

Frailty was not the problem for German women researchers eager for duty in the Antarctic. Gotthilf Hempel, director of the West German polar research institute in Bremerhaven, never wanted to send a mixed team because of the risk of pregnancy.

For years, the leader of the current expedition, Monika Puskeppeleit, was frustrated by this rule. Ever since finishing her medical degree at Heidelberg in 1984, she had been prodding Hempel to let her join the West German team. In 1987, when she was about to give up and ask the Australians if she could join their team, Hempel agreed to consider another solution - sending a women-only team. "I am a biologist and I believe in fecundity", explained Hempel. "A pregnancy in the isolation of the Antarctic can be fatal for both mother and child."

The Neumayer Station is equipped with a makeshift operating room for emergency procedures such as appendectomies. But help from the outside would be impossible during most of the winter, when temperatures reach $-46 \mathrm{C}^{\circ}$. Would Hempel not trust the researchers to avoid pregnancy in the Antarctic? "No", he said, "I do not trust [birth-control] procedures completely." Puskeppeleit and two geophysicists found two like-minded meteorologists and four technicians to complete the team. The team will measure seismic disturbances, as well as observing the Earth's magnetic field as part of the international project Intermagnet and collect data on the weather for global climate studies.

Puskeppeleit will gather data for a joint project with the German Aerospace Research Establishment (DLR). She will see if the bacterium bacillus subtilis is suitable as a "living sensor system" for measuring the effects of the seasonal stratospheric ozone deficiency in the Antarctic. Similar experiments with the bacterium have been carried out in space.

Unlike the larger US base at McMurdo, the German station is a temporary structure, consisting primarily of two large steel pipes. West Germany plans to invest in a permanent station to be built by the early 1990 )s. The German station is located at $70^{\prime} 37^{\prime \prime}$ south latitude, $8^{\prime} 22^{\prime \prime}$ west longitude off the Weddell Sea. The nearest other station belongs to South Africa and

is $200 \mathrm{~km}$ away.

\section{Parls}

FrancE, which is to host a meeting of Antarctic Treaty signatories on 19 October, is looking at alternatives to ratification of the Wellington Convention on the Regulation of Antarctic Mineral Resource Activities (CRAMRA). With only a few weeks left before signatories to the treaty have to make up their minds, the Parliamentary Office of Evaluation of Technological and Scientific Choices was asked to give its advice and organized a 4-day series of hearings open to the press.

The parliamentary office was set up in July 1983 and consists of eight senators and eight deputies whose task is to advise parliament on the consequences of scientific and technological policies. Their decision to invite a string of experts from marine biologist, Commander Jacques Cousteau, and the ecology group Greenpeace to senior civil servants and the head of the national petrochemical institute - to state their points of view in front of the press had no precedent.

CRAMRA aims to close a legal loophole in the existing treaty by limiting mineral exploration on the continent (see Nature 341,$93 ; 1989)$. Until the convention comes into force, all 16 signatories are bound by a moratorium on mineral exploration, which expires in November. So far, France and Australia have refused to ratify CRAMRA, saying that it will encourage, rather than simply limit,

Hempel said that if he had reservations about sending the all-female team, "I would not have let them go". They are not going purely for the adventure of it or just to show off, he said. Instead, "they take it as a natural right" that women should have an equal opportunity.

Steven Dickman

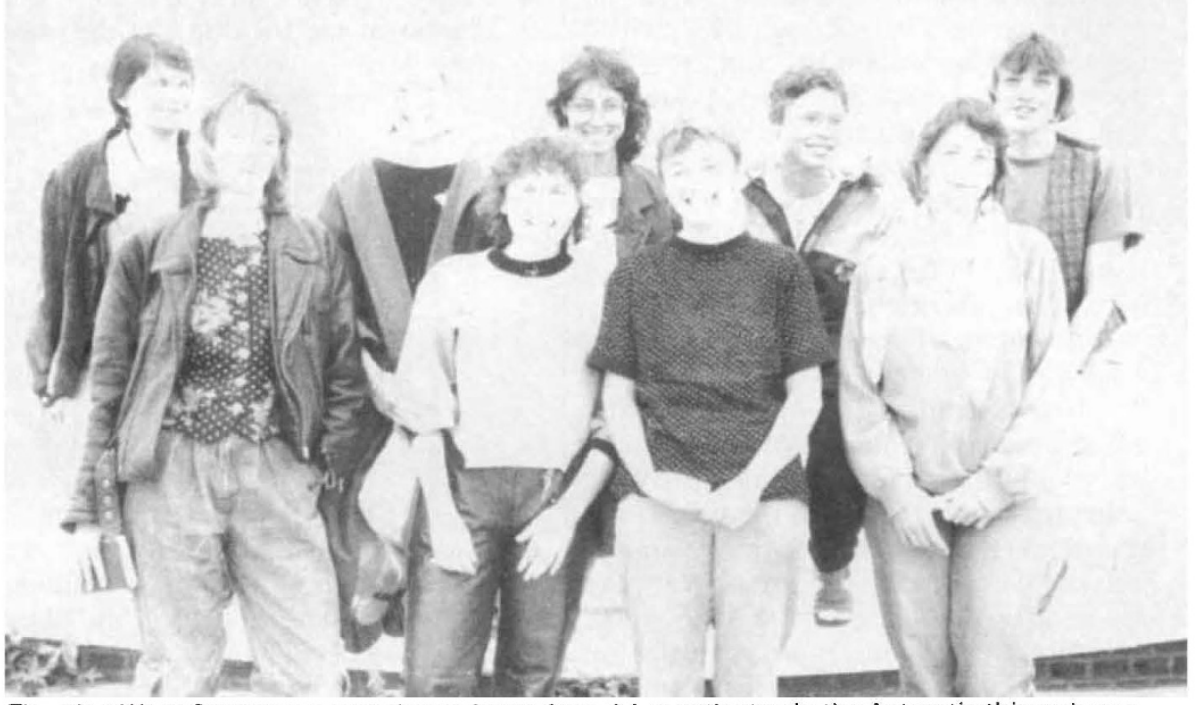

The nine West German women due to leave for a 14-month stay in the Antarctic this autumn.

\title{
France asks for advice
}

commercial exploration. Instead, they suggest that the Antarctic continent should be designated a world nature reserve, with only research activities authorized.

This position was last week endorsed by Remy Parmentier, of Greenpeace, and Cousteau, even though a ban on mineral exploration is unlikely to receive a unanimous vote by treaty signatories. The argument that the ban would be difficult to enforce, they say, also applies to the current moratorium. Lucien Montadert, director of the Institut Français du Pétrole, told the office that a search for oil in the Antarctic would not be technically feasible for 30 years, but added that, "if the possibility exists to look for oil, some day someone will look for it". Even if, for safety reasons, scientific geological surveys are carried out precisely where there is little likelihood of finding gas or oil, said Admiral Corbier, administrator of the French Antarctic Territories, the boundary between research and prospecting is often ill-defined.

Last Thursday, at the end of the session of expert testimony, it seemed likely that the office would recommend that France adopt a compromise position. Instead of ratifying CRAMRA, France will probably call for the existing moratorium to be extended until a competent authority is found to administer the Antarctic as a world nature reserve.

Peter Coles 